\title{
UTILIZATION AND CONSERVATION OF MEDICINAL AND AROMATIC PLANTS: A CASE STUDY FROM MWDR, NEPAL
}

\author{
Kabi Prasad Pokhrel ${ }^{*}$
}

\begin{abstract}
Mid Western Development Region (MWDR), a part of Nepali Himalayas, the globally significant and biologically diverse ecosystems, is remarkably rich in medicinal and aromatic plants, and other non-timber forest products (NTFPs). Government recorded data shows that about 700 species of herbal shrubs and NTFPs are found in the region and they are very important natural resources for human beings and for environmental balance. However, these vital and life supporting plants are in threats from deforestation, degradation, overuse and misuse. Unsustainable harvesting, improper storing, unfair trading, common property mismanagement, and policy environments have combined caused such valuable plants to vanish rapidly. The present paper based on empirical evidences points out that without people's participation in resource development, conservation and management it is difficult to enhance the production of locally available resources on one hand, and not possible to reduce the rate of poverty and environmental deterioration on the other. Moreover, the findings of the study emphasize on the need of integrated conservation and development activities through watershed management in order to promote the sustainable livelihoods of people in the region.
\end{abstract}

\section{INTRODUCTION}

Mid-Western Development Region (MWDR) of Nepal, a part of Central Himalayas, lies at the cross roads of floristic sub-regions i.e., between two major biogeographically realms: Palaearctic and the Indo-Malayan. This great geographical expanse of the region has resulted on enormous ecological diversity ranging from the tropical evergreen dense forest in the south to tundra types of open degraded vegetation in the north (CBS 2002). Thus, the region is rich in different sorts of forests, grassland communities, shrubs, and wetland ecosystems. The government data indicates that about 1400 species of medicinal herbs have been identified in Nepal; among them nearly 70 are found in the study region (NPC/IUCN, 1998). Further, the region's physiographic ruggedness has led to severe isolation of some mountain valleys and peaks, in turn facilitating a high level of endemism (Shrestha and Joshi 1996). These tremendous plant species contribute one of the very important natural resources for human beings, wild and domestic animals, other micro organism and for the environmental balance of the region. People in the hilly and mountainous regions have been involved in the collection and the trade of non-timber forest products (NTFPs) for income generation for a long period of time. Similarly, these plants have also been used

\footnotetext{
*Associate Professor, Research Division, Tribhuvan University, Kathmandu, Nepal
} 
in medicine for a long time. Hence, NTFPs plants have significant role and value in the subsistence agrarian economy of the region. At present, significant amount of forest revenue has been collected and basic forestry needs of the rural people have been fulfilled from the collection of NTFPs in this region. Most remarkably, such plants play an important role in maximizing the much needed environmental balance. Therefore, the medicinal herbs and other species of NTFPs have been attracting the researchers as a central theme of multi-disciplinary research for mapping, determining the extent, and their distribution pattern in order to develop future plan aiming at sustainable utilization and management of the valuable natural resources which are threatened due to deforestation, degradation, overuse and misuse. Further, the region has received relatively less attention on plant diversity investigation and market development from the government machinery. Thus, the biological, commercial, socio-economic and institutional aspects of the NTFPs need to be studied in detail (Edward 1995). Bhatta and Rawal (2001) have stated that the NTFPs plants have been exploited from the remote wild areas in the region by individual collectors and traded in unorganized due to in confusing policy environment. Kanel (2000) has also established the link between resource degradation and increasing human intervention in grassland communities where poor households collect NTFPs without any knowledge of ecological status and sustainable level of extraction of NTFPs from the forests and pasturelands. One can easily note that the increasing threats to environmental resources i.e. NTFPs are directly related to excessive anthropogenic activities such as uncontrolled harvesting, overgrazing, improper storing, unfair trading, defective property rights and shifting cultivation. Thus, human interventions are felt as responsible factors for extinction of plant species that should have been addressed as the important issues for sustainable development of natural resources. Various policies that pertain to this sector need to be re-examined with regard to the promotion of a community based resource management policy. Earlier studies reflect that efforts are needed to combine the value of culture and ecological diversity with detail interpretation of the related issues of conservation, development and local determination. The complex social and cultural issues related to poverty, resource degradation, indigenous aspiration and the political unrest are also to be analyzed in order to enhance the local capability for the control over natural resource with in ecological limitation (Ankersen 1999). Similarly, Russell and Jambrecina (2002) have highlighted a broader conservation perspective through a new kind of community involvement in the management of natural resources. Finding of the collaborative project of Tribhuvan University Nepal and University of Bergen, Norway points out that available aromatic and medicinal plants have to be prioritized by the national government machinery to enhance the economic productivity of such plants and to promote the ecological stability of the Himalayan region in Nepal (Chaudhary et al. 2007). Thus, resource management understanding and co-operation are required at multiple levels in which active partnership meets the needs of interested community groups co-operatively identifying local management objectives. Obviously, it is possible to reach the point of sustainable management of natural resources with due consideration to people's needs and their participation. 
The present study has been carried out with special focus on utilization and conservation pattern in the region and to suggest an appropriate management strategy by involving local people in the mission. To achieve these objectives extensive field work and literature survey have been made to gather required information on existing NTFP plant diversity in the region.

\section{DISTRIBUTION PATTERN}

The study region is situated in the western part of Nepal, between the Far Western Development Region (FWDR) in the west and Western Development Region in the east as well as the Tibetan Region of China in the north and Utter Pradesh of India in the south. (Figure 1).

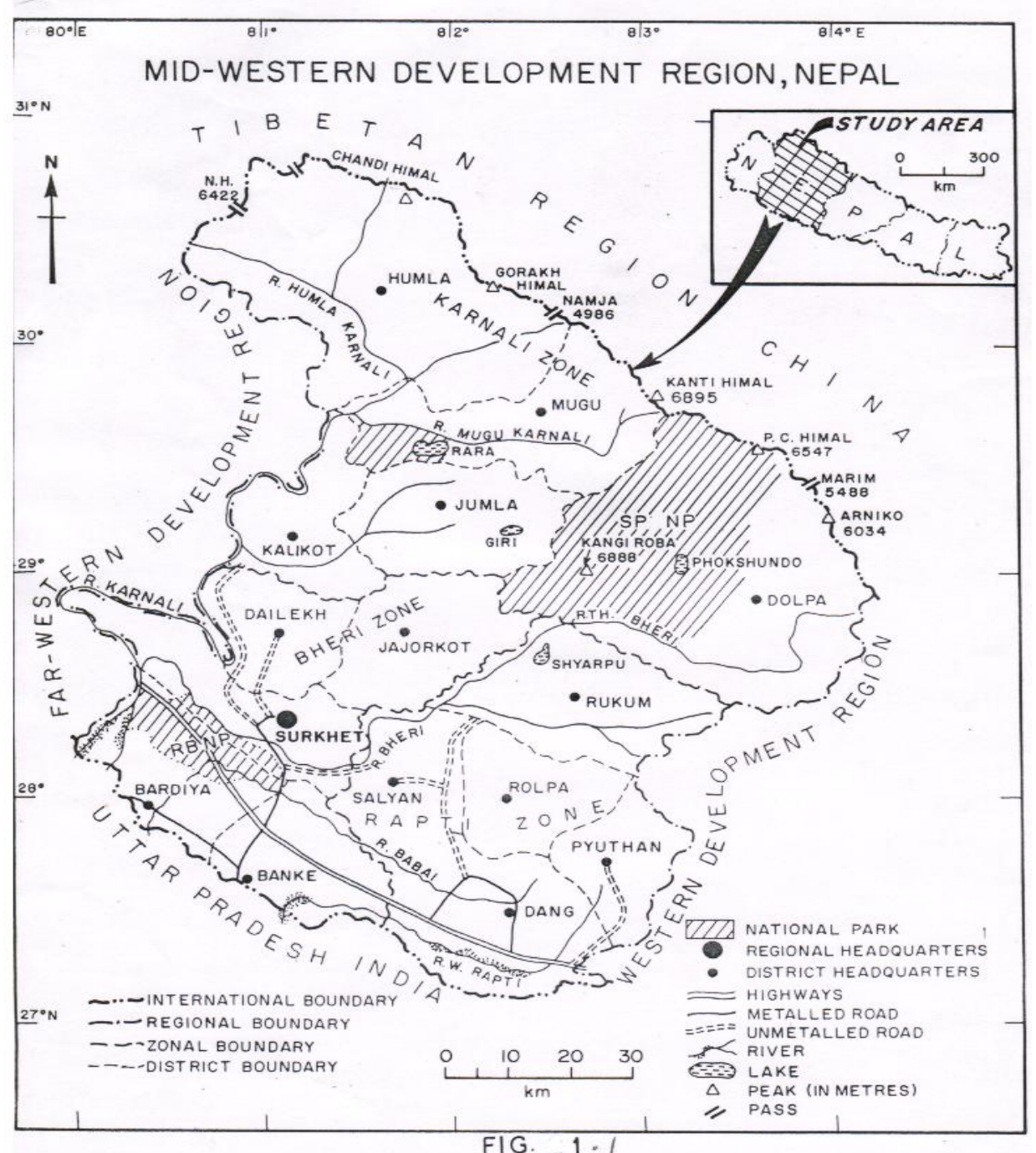


Region covers an area of 42,559 $\mathrm{Km}^{2}$ and an altitude ranging from of $129 \mathrm{~m}^{0}$ to $7,767 \mathrm{~m}$ above from mean sea level. Topographical features range from Tarai, a part of Indogangetic Plain in the south to mountainous rugged topography in the north. Due to a large difference in altitude, soil characteristics and climatic variability, the vegetation types range from the tropical evergreen forest in the south to the open degraded alpine bush communities in the north (Table 1). The prevailing forests in the southern part are mainly Sal and tropical mixed hard woods as well as lower mixed deciduous wood. In southern slopes of Mahabharata range and outer Himalaya, temperate forests consist of lower and upper mixed deciduous and coniferous forests whereas in the mountainous region, pine, deodar and oak forests and number of grass communities are observed. In the higher ranges, peaks and isolated inner mountain valleys climate changes into alpine and further this venial with very cold and dry weather. Very few flowering plants are found in higher altitude that complete their life cycle between 3-4 months.

Table 1. Climatic Zones and Vegetation Types

\begin{tabular}{|c|l|l|}
\hline \multicolumn{1}{|c|}{ Climatic zones } & \multicolumn{1}{c|}{ Types of vegetation } \\
\hline A & Tropical $(<1000 \mathrm{~m})$ & Sal, Jamun, Saj, Neem, Bel, Kusum and others. \\
\hline B & $\begin{array}{l}\text { Sub-tropical }(1000- \\
1500 \mathrm{~m})\end{array}$ & $\begin{array}{l}\text { Schema wallichan, Pinups, roxburghii, shrubs } \\
\text { and herbs. }\end{array}$ \\
\hline C & $\begin{array}{l}\text { Warm-temperate } \\
(1200-2000 \mathrm{~m})\end{array}$ & $\begin{array}{l}\text { Rhododendron, Utis, Chirpine, Bluepine, } \\
\text { Bamboos, and other mixed wood forest }\end{array}$ \\
\hline D & $\begin{array}{l}\text { Cold-temperate } \\
(2000-3000 \mathrm{~m})\end{array}$ & $\begin{array}{l}\text { Mixed broad-leaved wood, Acer, R } \\
\text { Rhododendron Mixed Bluepine oak, } \\
\text { Cedrus deodar, grasslands and shrubs. }\end{array}$ \\
\hline E & $\begin{array}{l}\text { Sub-alpine (3000- } \\
4000 \mathrm{~m})\end{array}$ & $\begin{array}{l}\text { Fir, Birch, Indica steppe herbs: Paris, picrorhiza } \\
\text { and Rheum. }\end{array}$ \\
\hline F & $\begin{array}{l}\text { Alpine }(4000-5000 \\
\text { m) }\end{array}$ & $\begin{array}{l}\text { Shrubs, grasslands, and bushy shrubs } \\
\text { G }\end{array}$ Naval $(>5000 \mathrm{~m})$ \\
\hline
\end{tabular}

Source: DOF, 2008, and Field Survey 2009.

It is evident from the table that the wide variation of geographical features across the region supports biological significance and species diversity. The location of the region and its geographic isolation create a region of high floral diversity with distinctive vegetation (Subedi 1998). Hence, the transitional location of the region between Holarctic and oriental biogeographical zones makes it rich in species diversity and broad range of habitats. From the medicinal and aromatic herbs as well as from other non-Timber Forest product plants point of view, the region has three important vegetation acnes. The cold temperate and higher area is much, rich in medicinal herbs like Yarsagumba, Kutki Panch Aunie, Stuwa, Chiraito etc. while in the warm temperate mid hill region which is 
home to large genera of valuable medicinal herbs and other important NTFPs major species include, Timur, Titepati, Chiraito, Tejpat, Satawari Pipal and others in the hot and wet Tarai region, Pipla, Kurilo, Sikakai, Haro, Barro, Neem, Bel, Jamun Tulsi are observed to be major NTRP plant species (Table 2).

Table 2. Important medicinal Trees, Herbs and Shrubs

\begin{tabular}{|c|c|c|c|}
\hline S.N. & Local Name & Scientific Name & Location \\
\hline 1. & Yarsagumba & $\begin{array}{l}\text { Cordyseps } \\
\text { sinensis }\end{array}$ & Mountain Region (3000-6000 m) \\
\hline 2. & Panch Aunle & $\begin{array}{l}\text { Dactylorbiza } \\
\text { batagirea }\end{array}$ & $\begin{array}{l}\text { Mountain and Hill Regions } \\
(3000-3500 \mathrm{~m})\end{array}$ \\
\hline 3. & Kutki & $\begin{array}{l}\text { Picrorhizo } \\
\text { scrophulariflora }\end{array}$ & Mountain Region (3500-4800 m) \\
\hline 4. & Okhar & Juglans regia & $\begin{array}{l}\text { Midland, Mahabharat lekh upto } \\
2500 \mathrm{~m}\end{array}$ \\
\hline 5. & $\begin{array}{l}\text { Timur/ } \\
\text { Nepalipepper }\end{array}$ & $\begin{array}{l}\text { Zanthoxy } \\
\text { lumarmatum }\end{array}$ & Hill Region (1100-2000 m) \\
\hline 6. & Chiraito & Swertia chirayita & Hill Region (1500-2500 m) \\
\hline 7. & Titapati & Indianwormwood & Hill Region up to $3000 \mathrm{~m}$ \\
\hline 8. & Majitho & Rubia manjith & Hill Region (1200-3500 m) \\
\hline 9. & Stuwa & $\begin{array}{l}\text { Paris } \\
\text { polyphyllasmith }\end{array}$ & $\begin{array}{l}\text { Mountain and Hill Regions } \\
(1800-3500 \mathrm{~m})\end{array}$ \\
\hline 10. & Bojho & Sweet flag & Mountain and Hill(2000-4000 m) \\
\hline 11. & Tulsi & o-cinum sarictum & $\begin{array}{l}\text { Tarai and Hill Regions up to } \\
1200 \mathrm{~m}\end{array}$ \\
\hline 12. & Lichens & $\begin{array}{l}\text { Parmelia } \\
\text { nepalensis }\end{array}$ & Mountain Region above 5000 m \\
\hline 13. & Chirpine & $\begin{array}{l}\text { Pinus } \\
\text { raoxburghill }\end{array}$ & $\begin{array}{l}\text { Mountain and Hill Regions } \\
(2000-4000 \mathrm{~m})\end{array}$ \\
\hline 14. & Bel & Aegle marcios & Tarai (up to $12000 \mathrm{~m}$ ) \\
\hline 15. & Neem & Azadirachtandica & Tarai Region $(1000 \mathrm{~m})$ \\
\hline 16. & $\begin{array}{l}\text { Jamun/Black } \\
\text { berry }\end{array}$ & Syzigium cumini & $\begin{array}{l}\text { Tarai and Hill Regions (up to } \\
2000 \mathrm{~m} \text { ) }\end{array}$ \\
\hline 17. & Pipal & Ficus Religiora & $\begin{array}{l}\text { Tarai and Hill Regions (up to } \\
3000 \mathrm{~m} \text { ) }\end{array}$ \\
\hline 18. & Tejpat & $\begin{array}{l}\text { Cinama mum } \\
\text { tamala }\end{array}$ & $\begin{array}{l}\text { Hill \& Mountain Regions (200- } \\
3000 \mathrm{~m} \text { ) }\end{array}$ \\
\hline 19. & Jatamanshi & $\begin{array}{l}\text { Nardostachys } \\
\text { grardifiora }\end{array}$ & $\begin{array}{l}\text { Hill and Tarai Regions (4000- } \\
2500 \mathrm{~m})\end{array}$ \\
\hline
\end{tabular}

Source: Field Survey 2009.

It is clear from the Table 2 that the plant diversity particularly in hill and mountain regions can be a driving force for sustainable livelihood if these plants 
will be managed properly. Thus, the NTFPs are valuable from the point view of socio-economic development and environmental balance in the region which needs to be treated as part of the human ecosystem.

\section{UTILIZATION OF MAPs}

The rich plant diversity of the region has been used by different nature of communities for various purposes such as edible food, medicine, fodder, agricultural tools, religious and other location wise purposes for a long time. This has proved that plants have a variety of uses in the region. From the point of view of utilization, these distinct but mutually non-exclusive categories of NTFPs have been identified as: locally used for subsistence purpose, potential for trade and commercially traded but all of the species whither there are locally used or commercially traded have been extracted from the forest by the poor households for a long time and this remains a traditional way of life of the people living in hill and mountain regions even today. Commercial species are traded through a series of traders for processing or distribution. Thus, the present trade channels do not provide high share of profits to local collector. At present it depends on a limited number of wholesalers. Hence, the NTFPs trading system appears to be less competitive, less in formed, and more vulnerable to prices caused by the intermediaries. In case of industrial utilization, there are neither enterprises nor industries for processing and manufacturing of NTFPs. Consequently, the NTFPs have been harvested in remote areas and are sold through a long marketing channel, which is inefficient and costly from the perspective of the local collectors. Edward (1996) found that harvesters of NTFPs receive only 32 percent of the final price in India. Though some efforts on NTFPs management and development have been initiated from the government, community forestry program and few NGOs through the awareness and management training of NTFP: MAPs, further, most of the NTFPs are collected from natural forest in the region. Prioritization of high value indigenous plants cultivation and development of future plan have not also been found in practice in the region. Thus it has adversely affected the region's ecological balance. All these issues are increasingly affecting the harmony between growing subsistence need of the local people and depleting natural resources. However, even at present, NTFPs have still been contributing significantly in the subsistence agrarian rural economy of the region by providing more than 12 percent of forest revenue and basic forestry needs to the rural people (Table 3). Moreover, there is an increasing demand of some species of MAPs in national and international levels.

Table 3. Revenue from NTFPs (in RS' 000)

\begin{tabular}{|l|c|c|}
\hline \multicolumn{1}{|c|}{ Sub-regions } & Rs. & Percent \\
\hline Mw Hill & 2,369 & 59.26 \\
\hline Mw Hill & 4,659 & 21.90 \\
\hline Mw Tarai & 134 & 0.39 \\
\hline Mw Dev Region & 7,162 & 12.39 \\
\hline
\end{tabular}

Source: DOF 2008. 
From the aforesaid discussion it is observed that there are enormous challenges before the region regarding alleviation of poverty and the sound management of natural resources. With increasing human requirement the natural resources like many species of NTFPs are in the process of extinction in this ecologically fragile and sensitive region on the one hand, and the benefits from the harvesting and trade of these plants have received only by the wholesalers on the other. This is informative to analyze the responses of concerned people about major constrains to and problems of NTFP regarding cultivation, production, conservation, development etc. In response, 15.87 percent of respondents perceived that there is no control in the extraction of NTFPs from the forest of the region. About 14.28 percent felt lack of research and survey activities on NTFPs distribution, and conservation while 12.69 percent noted the lack of awareness and dissemination of technology. Likewise 8.52 percent reported the inappropriate policy on restinct or banning the trade of NTFPs, 10.11 percent reported the existing of legal challenges and 8.33 percent undeveloped capital markets. Similarly the percent of respondents who were answering the lack of coordination between local inhabitants and government officials was 7.39 percent followed by their reporting lack of native seeds nursery, 34\% lack of medicinal herbs based enterprises, 6.82\% and lack of storing facility (4.39\%).

Table 4. Perceived Problems/Constraints for Utilization and Conservation of MAPs

\begin{tabular}{|l|c|}
\hline \multicolumn{1}{|c|}{ Problems/constraints } & $\%$ \\
\hline Over and uncontrolled extraction & 15.87 \\
\hline Lack of baseline survey & 14.28 \\
\hline Lack of awareness and dissemination of technology & 12.69 \\
\hline Lack of storing facility & 4.34 \\
\hline Legal unclear & 10.11 \\
\hline Undeveloped capital market & 8.33 \\
\hline High cost of transfer and transit & 4.76 \\
\hline Inappropriate Ban on trade & 8.52 \\
\hline Lack of co-ordination between stakeholders and government officials & 7.93 \\
\hline Lack of native beads nursery & 7.34 \\
\hline Lack of herbal based enterprises & 6.82 \\
\hline
\end{tabular}

Source: Field Survey 2009.

It is evident from the foregoing discussion that the lack of appropriate post harvesting techniques, existing policy environment and properties rights, unorganized and unfair market challenges and inefficient co-ordination between stake-holders and government official are serious problems before the region for 
sustainable utilization and conservation mission of NTFPs. It is, therefore, a welldefined property rights with clearly delineated responsibilities is required for the sustainable use and management of locally available resources in the region.

\section{MEASURES FOR MAPS CONSERVATION AND DEVELOPMENT}

- $\quad$ There is a need to conduct a scientific resource survey by involving local inhabitants, government officials and expertise for identifying of NTFPs including MAPs with a view to create reliable data base for the natural, resource plan in the region.

- Government efforts are essential to recognize all key players i.e., stakeholders of the NTFPs sectors: forest resource users, collectors, traders, manufactures and consumers in the policy formation to popularize the resource conservation movement at the national and regional levels.

- $\quad$ Community forest user groups should be facilitated and supported in order to use MAPs and other natural resources for income generation.

- $\quad$ Emphases must be laid on re-examining all revenue policies and regulations to encourage local people for collecting, cultivating and selling NTFP products.

- $\quad$ It is needed to create a mechanism of formally involving all legitimate stakeholders, especially more women, disadvantage groups and even rural educated unemployed youths for achieving the objectives of resources development and poverty alleviation.

- $\quad$ There is a need to simplify trade procedures to support small-scale business based on NTFPs in the region.

- $\quad$ Priority should be given for promoting the green enterprises that depend on MAPs and other NTFPs for integrating development and conservation in order to break the poverty environmental degradation cycle at the regional level.

- $\quad$ Stress should be on right advocacy of skill development in order to promote the peoples participation for community based resource management with especial focus on indigenous knowledge and experiences.

- $\quad$ Formulation a proper crop plan is the need of hour for cultivating valuable medicinal herbs and other NTFPs with a view to conserve the local plant species.

- $\quad$ Efforts are required to establish co-operation and co-ordination among the concerned authorities by applying interdisciplinary holistic approach for the effective resource planning and development in the region. 


\section{CONCLUSION}

Thus, it can be stated that the Mid Western Development Region is rich in NTFP plant diversity and has a large potential in national and international market. These are important for social and economic welfare of the local inhabitants. This valuable sector should promote production efficiency conservation, sustainable use and equitable sharing of benefits. By adopting these measures, degraded resources can be utilized efficiently by promoting an integrated conservation and development approach which create more direct incentives to local communities rather than imposing the government regulations that can never be enforced effectively. Similarly, participatory process of development can be more fruitful with enough external support to empower the local people to be able to get access to technology, information and required resources. Finally, co-ordination and co-operation among the concerned organizations, line agencies and the stakeholders are required for a multidisciplinary approach for the sustainable development of natural resources in the region.

\section{WORKS CITED}

Ankersen, T.T. 1999. Addressing the Conservation Conundrum in Mesoamerica: A Bioregional Case Study (234-345) in M.V. McGinnis (ed.) Bioregionalism. Rutledge, London.

Bhatta, D.D. and R.B. Rawa, 2001. Policy and Regulatory Environment in Relation of Jaributi Production in Nepal, in BSP/New ERA and EFEA Workshop Proceedings. Kathmandu.

CBS 2002. A Hand Book of Environmental Statistics Nepal. NPC, CBS, Kathmandu.

Chaudhary, R.P. 2007. Local Effects of Global Changes in the Himalayas: Manang Nepal. Tribhuvan University and University of Bergen, Norway, Kathmandu.

Edwards, D.M. 1996. Non Timber Forest Products Form Nepal: Aspects of the Trade in Medicinal and Aromatic Plants. Forest Research and Survey Centre, Ministry of Forests and Soil Conservation, HMG/N, Kathmandu.

Kanel, R. 2000. Analyzing Policy for Poverty Alleviation: an example from NonTimber Forest Product Sector. Banko Jankari. 10(2): 3-8.

NPC and IUCN 1988. Building on Success: the National Conservation Strategy for Nepal. The National Planning Commission, Nepal and the World Conservation Union, Kathmandu. 
Pokhrel, K.P 2009. Environment and Development Practice in Nepal: A Geographical Analysis. EDRC-Banke, Nepalgunj.

Russell, J. and M. Jambrecina, 2002. Wilderness and Cultural Landscapes: Shifting Management Emphases in the Tasmanian Wilderness World Heritage Area. Australian Geography. 33(2): 125-39.

Shrestha, T.B and R.M. Joshi 1996. Rare, Endemic and Endangered Plants of Nepal. World Wildlife Fund, Kathmandu.

Subedi, B.P. 1998. Participatory Utilization and Conservation of MAPs: A Case From Western Nepal Himalaya. Paper Presented in the International Conference on MAPs held at Bangalore, India. 